\title{
DO WE KNOW BEETLES? LESSONS FROM NEW RECORDS OF CERAMBYCIDAE (COLEOPTERA) FOR NOVA SCOTIA
}

\author{
DAVID B. McCORQUODALE ${ }^{*}$ and SØREN BONDRUP-NIELSEN ${ }^{2}$ \\ ${ }^{1}$ Department of Behavioural and Life Sciences \\ University College of Cape Breton \\ Sydney, Nova Scotia, B1P $6 L 2$ \\ ${ }^{2}$ Department of Biology \\ Acadia University \\ Wolfville, Nova Scotia, BOP 1 XO
}

\begin{abstract}
The long-horned beetles (Coleoptera: Cerambycidae) are taxonomically relatively well known in North America and can potentially serve as an important forest biomonitoring tool. For such a tool to work accurate distributional data are required. We compared the status of cerambycids for Nova Scotia based on specimens in collections with two recent compilations that include distributional information, one for Canada and one for northeastern North America. We found major discrepancies. The two compilations reported a total of 55 species, while 87 species were in the collections examined. An accurate and up to date inventory is essential. This is underscored by the recent concern for the "invasion" of the Brown Spruce Long-horn Beetle, Tetropium fuscum, in Nova Scotia that was first collected more than 10 years ago, but misidentified. Both regional and national collections need to be supported to ensure effective strategies for conservation and forest management.
\end{abstract}

En Amérique du Nord, les longicornes (Coléoptères : Cérambycidés) sont assez bien connus sur le plan taxinomique et pourraient constituer un outil important dans la surveillance biologique des forêts. Pour qu'un tel outil soit efficace, il faut disposer de données précises sur la répartition des insectes. Nous avons comparé la situation des Cérambycidés de la Nouvelle-Écosse, établie à partir de spécimens de collections, à deux compilations récentes qui comprennent des données relatives à la répartition, à savoir une pour le Canada (Bousquet, 1991) et une pour le nord-est de l'Amérique du Nord (Dowie et Arnett, 1996). Nous avons découvert des différences notables. Les deux compilations font état d'un total de 55 espèces, tandis que 85 espèces ont été recensées dans les collections examinées. Il est essentiel d'effectuer un inventaire précis et à jour. Cette nécessité est soulignée par le problème récent de l' « envahissement » du longicorne brun de l'épinette (Tetropium fuscum) en Nouvelle-Écosse, qui avait été récolté pour la première fois il y a plus de 10 ans, mais mal identifié. II faut soutenir les collections régionales et nationales pour assurer le succès des stratégies de conservation et d'aménagement des forêts.

\section{Introduction}

The long-horned wood boring beetles, the family Cerambycidae, are relatively well known in North America. The taxonomy, identification, natural history, economic impact and distribution are well known compared to most other groups of beetles. The revisions by Linsley and Chemsak provide a comprehensive and solid taxonomic foundation for the family (Linsley 1962a, 1962b, 1963, 1964, Linsley \& Chemsak 1972, 1976, 1984, 1995, 1997, Chemsak 1996). The recent pictorial field guide by Yanega (1996) set out to provide a tool so that non-specialists could identify cerambycids in northeastern North America to species. Yanega (1996) produced his field guide because of his view that cerambycids offered one of the best opportunities for forest biomonitoring by non-professionals. He argued that cerambycids would be an excellent choice because they are not plants, they can be sampled adequately and they have the potential to be reasonable indicators of habitat differences. As consumers of wood, cerambycids have attracted the attention of applied entomologists and foresters, resulting in many studies on their biology and relations with plants (reviewed in Linsley

\footnotetext{
* Author to whom correspondence should be addressed.
} 
1961, Baker 1972, Safranyik \& Moeck 1995, Yanega 1996). Cerambycids include some of the largest and most colourful beetles in North America. As a result insect collectors have pursued them and they are well represented in collections. These collectors have provided the impetus and data for comprehensive lists for some areas (e.g Gosling 1973, Gosling \& Gosling 1977, Laplante et al. 1991, Dearborn \& Donahue 1993). However, no such comprehensive list is available specifically for Nova Scotia. The occurrence of species of cerambycids in Canadian provinces and the northeastern United States, has been compiled twice recently, by McNamara in the 'Checklist of Beetles of Canada and Alaska' (Bousquet 1991) and more recently by Downie \& Arnett (1996) in 'The Beetles of Northeastern North America'.

We became interested in wood boring beetles through projects designed to study the influence of land use and forestry practices on beetles (e.g. Kehler et al. 1996). As soon as we started identifying Cerambycidae collected in Nova Scotia we realized that many of the species we were collecting were not recorded in the two recent compilations. A first step in species level conservation is a reasonable inventory. The inventory provides the basis to check for species with low populations or vulnerable status. An inventory is also important in the ability to detect invasive species, which may cause widespread ecological problems. Without attention to a basic inventory, it is difficult to have the expertise available to recognize recent invaders. The importance of this has been underscored in Nova Scotia with the recent recognition of the Brown Spruce Long-horn Beetle, Tetropium fuscum, despite it being in the province for more than a decade (Forestry Canada 2000, Smith \& Hurley 2000).

We therefore set out to assess the strengths and weaknesses of the two recently published compilations by comparing these lists with the cerambycids in six small insect collections within the province of Nova Scotia and four larger collections in central Canada. We report here new information on the occurrence of cerambycids in Nova Scotia and we make suggestions for better distribution of information and better use of extant natural history collections.

\section{Methods}

All pinned specimens of Cerambycidae from Nova Scotia were examined in five insect collections in Nova Scotia, Acadia University (ACAD), Nova Scotia Department of Natural Resources (NSDNR), Nova Scotia Museum of Natural History (NSMNH), St. Francis Xavier University (STFXU) and University College of Cape Breton (UCCB), between 1996 and 1998. All pinned specimens of Cerambycidae from Nova Scotia in the collections of the Royal Ontario Museum (ROM), Toronto, Ontario, Canadian Museum of Nature (CMN), Aylmer, Quebec, Canadian National Collection of Insects, Arachnids and Nematodes, Agriculture and Agri-Food Canada, Ottawa $(\mathrm{CNCl})$ and the Canadian Forestry Service, Atlantic Forestry Centre, Fredericton (CFSF) were examined in 1997 and 1998. All specimens were either identified or previous identifications confirmed using Yanega (1996), supplemented by the revisions by Linsley (1962a,b, 1963, 1964) and Linsley \& Chemsak (1972, 1976, 1984, 1995) and references therein. Nomenclature and taxonomy follows Yanega (1996).

The list of species found in the collections was compared with two lists for Nova Scotia: McNamara's (1991) list of Cerambycidae in 'Checklist of Beetles of Canada and Alaska' and Downie \& Arnett's (1996) 'The Beetles of Northeastern North America'. A more recent online version of Bousquet (1991) is available through the $\mathrm{CNCl}$ website, but it does not include any additions to the list of Cerambycidae for Nova Scotia. 
Data from the label of each specimen of species not included in McNamara (1991) is presented in the form: county, locality, date or range of dates collected, collector, number of specimens if more than one, and institution. Other information on the label is not generally included. Since the county was not included on most labels, in most cases the county is implied from the locality information.

\section{Results}

The survey of collections revealed specimens of 87 species of Cerambycidae from Nova Scotia based on examination of about 1500 specimens. This compares with totals of 51 species from Nova Scotia in 'The Checklist of Beetles of Canada and Alaska' (McNamara 1991) and 23 species in 'The Beetles of Northeastern North America' (Downie \& Arnett 1996). The total number of species reported for Nova Scotia is 91, including species not seen in any of the collections. No specimens of three of the 51 species in McNamara (1991) were seen: Semanotus ligneus, Xylotrechus quadrimaculatus and Typocerus acuticauda. One of these, T. acuticauda, is included from Nova Scotia in Downie \& Arnett (1996). Additionally Downie \& Arnett (1996) report Brachyleptura vagans from Nova Scotia and no specimens were found. Downie \& Arnett (1996) include five species that are not on McNamara's (1991) list that were found in the collections: Anthophylax cyaneus, Pygoleptura nigrella, Sachalinolobia rugipennis, Clytus ruricola, and Aegomorphus modestus.

In Section I below, 39 species not included in McNamara (1991) and data supporting their occurrence in Nova Scotia are listed. Label data for all specimens are included for species with fewer than 10 records. For species with more than 10 records, only the number of records for each county is included. In Section II we list the species included in either McNamara (1991) or Downie \& Arnett (1996), but are not represented by specimens in the collections examined.

\section{Species not reported for Nova Scotia in 'Checklist of the Beetles of Canada and Alaska'}

\section{Aseminae}

Asemum striatum (Linné)

Thirty one records and 58 specimens from Antigonish (1), Cape Breton (1), Colchester (9), Cumberland (2) Guysborough (2), Halifax (8), Hants (4), and Lunenburg (4) Counties

This species is widespread in North America, from the Yukon to Florida, wherever there are coniferous trees (Chemsak 1996). McNamara (1991) reports it from New Brunswick and Newfoundland in Atlantic Canada, while Downie \& Arnett (1996) do not record it from Atlantic Canada or northern New England. From the specimens available, it appears to be widespread in Nova Scotia, as would be expected from a province with large stands of its hosts, spruce (Picea spp.) and balsam fir (Abies balsamea) (Chemsak 1996, Linsley \& Chemsak 1997).

Tetropium fuscum (Fabricius)

Halifax, Point Pleasant Park, 22 June 1990, Ballard, R, NSMNH

Halifax, Point Pleasant Park, 22 June 1990, Robertson, S, NSMNH

Halifax, Point Pleasant Park, 28 June 1990, Harding, G, 3, NSMNH

Halifax, Point Pleasant Park, 29 June 1990, Robertson, S, 11, NSMNH 
This species is widely distributed in northern Europe (Bily \& Mehl 1989) and only known from the Halifax area in North America (Forestry Canada 2000, Smith \& Hurley 2000). These specimens were collected during a project designed to assess the impact of bark beetles on the health of spruce trees in Point Pleasant Park (Robertson 1990). Originally they were identified as the very similar congener, T. cinnamopterum and about ten years later it was realized they were a European species (Forestry Canada 2000, Smith \& Hurley 2000). This species has been the focus of an eradication program and surveys to determine the extent of its distribution in Nova Scotia were undertaken in 2000 and 2001. Reports from the Canadian Forestry Service and the Canadian Food Inspection Agency, the two bodies responsible for this work, should be consulted for up to date information on its status in the Halifax area (Forestry Canada 2000).

\section{Tetropium schwarzianum Casey}

Halifax, Point Pleasant Park, 29 June 1990, Robertson, S, NSMNH

This species is widely distributed, but not common, from Minnesota east and south to North Carolina and a record for southern Nova Scotia is included on the distribution map in Chemsak (1996). McNamara (1991) reports it from Ontario, Quebec and Newfoundland. Downie \& Arnett (1996) do not record it in Atlantic Canada or northern New England, although it is known from Maine (Dearborn \& Donahue 1993). We have seen only the one specimen from Halifax, presumably different from the record in Chemsak (1996). Larvae feed on pines, Pinus spp. (Chemsak 1996). The specimen from Point Pleasant Park was collected during a survey of bark beetles in this urban park (Robertson 1990).

\section{Lepturinae}

Desmocerus palliatus (Forster)

Cumberland, Amherst, 14 June 1992, Ogden, J, 2, NSDNR

There are records of this species from Newfoundland and New Brunswick in Atlantic Canada (McNamara 1991). Downie \& Arnett (1996) include reports from two states in northern New England. Larvae feed on the roots of the Common Elderberry, Sambucus canadensis (Linsley \& Chemsak 1972), which is more common in central Nova Scotia, than elsewhere in the province (Roland 1998).

Acmaeops proteus proteus (Kirby)

Colchester, Masstown, 29 June 1990, Smith, TD, NSDNR

Colchester, Masstown, 6 July 1990, Smith, TD, NSDNR

Hants, Mount Uniacke, 14 June 1952, Ferguson, DC, NSMNH

Hants, Stanley, 24 June 1992, Ogden, J, NSDNR

This is a widespread species, known from Alaska to New Brunswick, Labrador and Newfoundland (McNamara 1991). Downie \& Arnett (1996) record it only from Newfoundland in Atlantic Canada. Larvae feed under the bark of a variety of conifers (Linsley \& Chemsak 1972).

Analeptura lineola (Say)

Cumberland, East Leiscester, 28 June 1995, Corkum, C, ACAD

Guysborough, Melopseketch Lake, 28 June 1995, Corkum, C, ACAD

Guysborough, Borseo, 13 July 1995, Corkum, C, ACAD

McNamara (1991) reports this species from Ontario, Quebec and New Brunswick in Canada, while Linsley \& Chemsak (1976) describe the range as "Ontario to Florida to midwestern states". Dearborn \& Donahue (1993) state that it is found statewide 
and has been collected from balsam fir, pine and on blossoms of sumac. Downie \& Arnett (1996) do not include any reports from Atlantic Canada or northern New England. Larvae feed on birch, other hardwoods and pines (Linsley \& Chemsak 1976, 1997, Yanega 1996).

Anastrangalia sanguinea (LeConte)

Colchester, Debert, 16 July 1992, Georgeson, E, NSDNR

This is another widespread species across northern North America, known from Alaska to New Brunswick and reported for New Brunswick (Downie \& Arnett 1996). It is known from many places in Maine where it has been collected from balsam fir (Dearborn \& Donahue 1993). Pines are the hosts through much of its range (Linsley \& Chemsak 1972).

Anthophylax cyaneus (Haldeman)

Nineteen records, 21 specimens, from the Counties of Colchester (2), Cumberland (3), Guysborough (2), Halifax (4), Inverness (2), Lunenburg (4), Pictou (1), and Yarmouth (1).

McNamara (1991) reports this species only from Ontario, Quebec and New Brunswick. Downie \& Arnett (1996) include records from Nova Scotia as well as two states in northern New England. Larvae are catholic in their choice of food, using hardwoods of many species and probably some conifers as well (Linsley \& Chemsak 1972).

Brachyleptura rubrica (Say)

Pictou, Pictou, 8 July 1942, Ferguson, DC, NSMNH

Pictou, Pictou, 18 July 1942, Ferguson, DC, NSMNH

This species was known from Ontario, Quebec and New Brunswick (McNamara 1991) and from Maine (Dearborn \& Donahue 1993). However Downie \& Arnett (1996) did not report it from Atlantic Canada or northern New England. Larvae feed on decaying hardwoods (Linsley \& Chemsak 1972, 1997), probably beech (Fagus grandifolia) and oak in Nova Scotia.

\section{Gnathacmaeops pratensis (Laicharting)}

Cape Breton, Sydney, UCCB, 14 July 1986, Tynski, S, UCCB

Colchester, Masstown, 15 June 1990, Smith, TD, NSDNR

Cumberland, Amherst, 25 June 1994, Ogden, J, NSDNR

This is another species that is widespread across northern North America, known from Alaska to New Brunswick, Labrador and Newfoundland (McNamara 1991). Downie \& Arnett (1996) record it from Maine, but not from Atlantic Canada. The larvae feed on conifers (Linsley \& Chemsak 1972).

\section{Leptura plebeja Randall}

Cape Breton, Georges River, 31 July 1996, McCorquodale, DB, UCCB

Inverness, Kenloch, 12 Aug 1991, Slade/Rolfe, UCCB

This species was known from Manitoba through to New Brunswick (McNamara 1991 ) and Downie \& Arnett (1996) report it from New Brunswick and Maine. The larvae feed on conifers (Linsley \& Chemsak 1972). It is one of the few cerambycids reported to use Red Spruce, Picea rubens, as a host (Linsley \& Chemsak 1997). The two specimens from Nova Scotia are from Cape Breton Island where Red Spruce is very rare. 
Lepturopsis biforis (Newman)

Cape Breton, Sydney, UCCB, 19 August 1985, Tynski, S, UCCB

Digby, Belliveau, 2 August 1984, Neil, K, NSMNH

Hants, Uniacke, 29 August 1968, Doleman, P, NSMNH

Inverness, Cranton Section, 24 August 1959, no data, CFSF

This species is known from Ontario, Quebec and New Brunswick (McNamara 1991) and from Maine (Dearborn \& Donahue 1993). However Downie \& Arnett (1996) did not report it from Atlantic Canada or northern New England. Larvae feed on both hardwoods and conifers (Linsley \& Chemsak 1972).

Pygoleptura nigrella (Say)

Guysborough, Archibald Mills, 19 July 1994, Kehler, D, ACAD

This is a widespread species across northern North America from Alaska to New Brunswick, Labrador and Newfoundland (McNamara 1991). Downie \& Arnett (1996) report it from Nova Scotia and Newfoundland in Atlantic Canada and Maine in northern New England. Larvae feed on decaying conifers (Linsley \& Chemsak 1976, 1997).

Rhagium inquisitor (Linné)

Forty four records, 59 specimens, from Antigonish (2), Cape Breton (4), Colchester (7), Cumberland (1), Guysborough (1), Halifax (14), Hants (3), Inverness (1), Lunenburg (7), Pictou (2), and Queens (2) Counties

This is a widespread species with a wide distribution in Europe and across northern North America from theYukon to Newfoundland (Linsley \& Chemsak 1972, McNamara 1991). Downie \& Arnett (1996) do not record it from Atlantic Canada or northern New England. The larvae feed on the cambium of a variety of conifers (Linsley \& Chemsak 1972, 1997).

Sachalinobia rugipennis rugipennis (Newman)

Victoria, north of Wreck Cove Reservoir, 13 June 1996, 2, Lauff, R, STFXU

Halifax, Tomahawk Lake, May 1970, Doleman, P, Gilhen, J, NSMNH

This species has a northern distribution with records from Manitoba to New Brunswick in Canada (McNamara 1991). Downie \& Arnett (1996) report it for both New Brunswick and Nova Scotia and all three states in northern New England. The larvae feed on spruce and pine (Linsley \& Chemsak 1972).

\section{Cerambycinae}

Enaphalodes rufulus (Haldeman)

Lunenburg, Bridgewater, 20 July 1949, Ferguson, DC, NSMNH

This species was reported from Ontario and Quebec in Canada (McNamara 1991, Linsley 1963). Downie \& Arnett (1996) did not record it from Atlantic Canada, but did record it in New Hampshire, as far north as the map in Linsley (1963) illustrates the range. The larvae feed primarily on branches of living Red Oak, Quercus rubra (Baker 1972). Red Oak is widespread in Nova Scotia and grows in the Bridgewater area (Hosie 1990, Roland 1998).

Anelaphus parallelus (Newman)

Annapolis, Annapolis Royal, 13 June 1949, Ferguson, DC, 21, NSMNH

Annapolis, Annapolis Royal, 17 June 1949, Ferguson, DC, 2, NSMNH

Kings, Kentville, 08 August 1911, Frost, CP, ROM 
Lunenburg, Bridgewater, 28 May to 5 June 1965, Wright, B, NSMNH

Lunenburg, Bridgewater, 30 June 1965, Dept of Forestry, 4, NSMNH

Lunenburg, Bridgewater, 30 June 1965, Wright, B, 6, NSMNH

Lunenburg, Bridgewater, July 1965, no data, 6, CFSF

Queens, Tobeatic Game Sanctuary, 12 March 1953, no data, 4, CFSF

Queens, no location, 03 March 1944, no data, CFSF

This species is recorded in Canada from Manitoba to Quebec (McNamara 1991).

Downie \& Arnett (1996) do not include records from Atlantic Canada or northern New England, although it is known from Maine (Dearborn \& Donahue 1993). The northern most locations on the range map in Linsley (1963) are in central Massachusetts and eastern Ontario. Larvae feed on twigs of a wide variety of deciduous trees and shrubs, with a preference for oak (Linsley 1963).

Anelaphus villosus (Fabricius)

Annapolis, Lake Kejimkujik, 9 August 1961, Ferguson, DC, NSMNH

This species is recorded in Canada from Manitoba to Quebec (McNamara 1991). Downie \& Arnett (1996) do not include records from Atlantic Canada or northern New England, although it is known from Maine (Dearborn \& Donahue 1993). The northeastern most locations on the range map in Linsley (1963) are in eastern Ontario, eastern New York and western Massachusetts. Like its congener, larvae feed on twigs of a wide variety of deciduous trees and shrubs (Linsley 1963).

\section{Molorchus bimaculatus bimaculatus Say}

Guysborough, Salem Lake, 15 to 30 June 1997, Bishop, DJ, ACAD

Lunenburg, Bridgewater, 19 June 1965, Wright, B, 4, NSMNH

Lunenburg, Bridgewater, 30 June 1965, Wright, B, 3, NSMNH

This species is known from Alberta east to Quebec in Canada (McNamara 1991). Downie \& Arnett (1996) report it to be widespread in the northern New England and Atlantic Canada. The Bridgewater specimens were collected in window trap in Red Oak, Quercus rubra. The larvae of this subspecies feed on a wide variety of deciduous trees and shrubs (Linsley 1963).

Phymatodes dimidiatus (Kirby)

Inverness, Whycocomagh, 9 July 1967, Wright, B, 2, NSMNH

Inverness, Whycocomagh, 20 July 1980, Wright, B, NSMNH

Hants, Stanley, 8 July 1982, Leblanc, M, NSDNR

This species has a mainly western distribution (Linsley 1964), but is known from Alaska to as far east as New Brunswick in Canada (McNamara 1991). Downie \& Arnett (1996) do not record it from Atlantic Canada or northern New England, although it is known from Maine (Dearborn \& Donahue 1993). Larvae live under the bark of coniferous trees (Linsley 1964).

Phymatodes testaceus (Linné)

Halifax, Halifax, 20 August 1992, Yarn, B, 7, NSMNH, firewood in basement Lunenburg, Petite Riviere, 10 July 1957, Ferguson, DC, NSMNH, Lunenburg, Petite Riviere, 12 July 1957, Ferguson, DC, 3, NSMNH, Lunenburg, Chester, 16 July 1969, Wright, B, NSMNH, Lunenburg, Big Mushamush Lake, 30 June 1979, Wright, B, NSMNH, Lunenburg, Sunnybrook, 19 July 1992, Wright, B, 12, NSMNH, firewood in basement In Canada, this species has been recorded only from Quebec and Ontario (McNamara 1991). Downie \& Arnett (1996) do not record it from Atlantic Canada or northern New 
England, although it is known from Maine (Dearborn \& Donahue 1993). This is a holarctic species with a wide range in Europe, North Africa and North America (Linsley 1964). Larvae live under the bark of a variety of hardwoods, especially oak (Linsley 1964).

\section{Megacyllene robiniae (Forster)}

Ten records, 24 specimens, from Colchester (2), Halifax, (6) and Kings (2) Counties

This species is known from Ontario and Quebec in Canada (McNamara 1991).

Downie \& Arnett (1996) do not record it from Atlantic Canada or northern New England, although it is known from Maine (Dearborn \& Donahue 1993). The host is the ornamental Black Locust, Robinia pseudoacacia, which has been widely planted in Nova Scotia (Roland 1998). Most records are of adults reared from ornamental trees.

\section{Glycobius speciosus (Say)}

Colchester, Brookfield, 22 July 1985, Sutherland, P, NSDNR

Colchester, Stewiacke, 22 July 1979, McLennan, G, NSMNH

Cumberland, Springhill, 12 August 1943, TKB Collection, NSMNH

Halifax, Portuguese Cove, 05 August 1986, Purcell, M, 2, NSMNH

Kings, Kentville, 12 July 1979, no data, NSMNH

The Sugar Maple Borer is known from Ontario and Quebec in Canada (McNamara 1991). Downie \& Arnett (1996) do not record it from Atlantic Canada or northern New England, although it is known from Maine (Dearborn \& Donahue 1993). The larvae feed on Sugar Maple (Acer saccharum) (Linsley 1964).

\section{Calloides nobilis (Harris)}

Lunenburg, Bridgewater, 27 June 1993, Selig, GD, NSMNH

McNamara (1991) records this species from Ontario and Quebec in Canada. Downie \& Arnett (1996) do not record it from Atlantic Canada or northern New England, although there are two records for Maine (Dearborn \& Donahue 1993). Larvae feed on hardwoods including ash and oak (Linsley 1964). This specimen was brought to a museum in Lunenburg County and the details of its capture are not clear.

\section{Xylotrechus annosus annosus (Say)}

Cumberland, Springhill, 1 June 1954, Gray, RD, NSMNH

Halifax, Elderbrook, 6 June 1996, Ogden, J, NSDNR

This species has a wide range across Canada from the North West Territories to New Brunswick (McNamara 1991, Linsley 1964). Downie \& Arnett (1996) record it in New Brunswick and Maine. Willow and poplar are the host plants (Linsley 1964).

\section{Xylotrechus colonus (Fabricius) \\ Cumberland, Parrsboro, 17 August 1996, Ogden, J, NSDNR \\ Halifax, Halifax, 20 April 1974, Wright, B, NSMNH \\ Lunenburg, Lunenburg, 5 February 1973, Wright, B, NSMNH \\ Lunenburg, Canaan, 4 January 1985, Hirtle, C, NSMNH \\ Victoria, Baddeck, 20 June 1993, no data, NSDNR}

In Canada, this species was known from Manitoba to New Brunswick (McNamara 1991) and Downie \& Arnett (1996) reported it from three states in Northern New England. Three of the Nova Scotia records are of adults that emerged from firewood during the winter or early spring. Therefore the specific location where these individuals lived is unknown. Larvae feed on a wide variety of deciduous trees (Linsley 1964). 
Clytus ruricola (Olivier)

Eleven records, 13 specimens from Cape Breton (1), Colchester (3), Cumberland (1), Lunenburg (3), Pictou (1), Richmond (1) and Victoria (1) Counties

This is a widespread species in Canada with records from Alberta to New Brunswick (McNamara 1991, Linsley 1964). Downie \& Arnett (1996) report it from Nova Scotia plus two states in northern New England. Larvae feed on the wood of many species of deciduous trees, including maples and birches (Linsley 1964).

\section{Lamiinae}

Psenocerus supernotatus (Say)

Queens, Lake Kejimkujik, 2 July 1957, Ferguson, DC, NSMNH

In Canada, this species is known from Manitoba to New Brunswick (McNamara 1991) and Downie \& Arnett (1995) report it from Maine and Vermont in northern New England. Larvae feed on a wide variety of deciduous shrubs and trees (Linsley \& Chemsak 1984, 1997).

\section{Pogonocherus mixtus Haldeman}

Lunenburg, Chester, 5 August 1991, Georgeson, E, NSDNR

This is a widespread species in North America, known from the Yukon to New Brunswick in Canada (McNamara 1991). Downie \& Arnett (1996) report it from three states in northern New England, but not from Atlantic Canada. Larvae feed on both conifers and some deciduous shrubs (Linsley \& Chemsak 1984, 1997).

Aegomorphus modestus (Gyllenhal)

Digby, Lake Kejimkujik NP, 9 Aug 1961, no data, NSMNH

Digby, Lake Kejimkujik, 3 July 1968, Wright, B, NSMNH

Kings, Centreville, 23 July 1949, Ferguson, DC, NSMNH

Kings, Kentville, 17 July 1985, Neil, K, NSMNH

Lunenburg, Big Mushamush Lake, 4 August 1976, 2, Wright, B, NSMNH

This species is known from Manitoba, Ontario and Quebec in Canada (McNamara 1991) and from two states in northern New England (Downie \& Arnett 1996). Larvae feed on a wide variety of deciduous trees (Linsley \& Chemsak 1984, 1997).

\section{Astylopsis sexguttata (Say)}

Hants, Mount Uniacke, 1 August 1968, 1, Wright, B, NSMNH

Nova Scotia, County unknown, St George, 09 August 1939, no data, CFSF

This species is known from Manitoba, Ontario and Quebec in Canada (McNamara 1991). It is not recorded from northern New England or Atlantic Canada in Downie \& Arnett (1996). Larvae feed on a variety of conifers (Linsley \& Chemsak 1995, 1997).

Sternidius variegatus (Haldeman)

Antigonish, Brierly Beach, 12 July 1956, Ferguson, DC, NSMNH

Inverness, Margaree Forks, 26 July 1991, Georgeson, E, CNCI

Inverness, Margaree Forks, 22 August 1995, Ogden, J, NSDNR

Victoria, Baddeck Bridge, 29 July 1970, Wright, B, 2, NSMNH

This is a widespread species, known from Alberta to New Brunswick in Canada (McNamara 1991) and Maine (Dearborn \& Donahue 1993). Downie \& Arnett (1996) do not record it from Atlantic Canada or northern New England. Larvae feed on a wide variety of trees and shrubs (Linsley \& Chemsak 1995, 1997). 
Urographis fasciatus (DeGeer)

Lunenburg, Big Mushamush Lake, 21 July 1978, Wright, B, NSMNH

Lunenburg, Riverport, 26 July 1987, Corkum, K, NSMNH

Queens, White Point Beach, 8 September 1954, Ferguson, DC, NSMNH

Queens, Kejimkujik National Park, SI/MAB Plot, 11 July 1994, no data, CFSF

This species is reported from Ontario and Quebec in Canada (McNamara 1991) and from two states in northern New England in Downie \& Arnett (1996), but not from Atlantic Canada. Larvae feed on a wide variety of trees and shrubs (Linsley \& Chemsak 1995, 1997).

\section{Saperda calcarata Say}

Fifty seven records, 72 specimens from Annapolis (1), Cape Breton (2), Colchester (12), Cumberland (9), Digby (1), Halifax (11), Hants (1), Inverness (2), Kings (2), Lunenburg (4), Pictou (2), Queens (5), Shelburne (2), Victoria (1), and Yarmouth (2) Counties

This is a widespread species known from British Columbia to Quebec in Canada (McNamara 1991). It is one of the few cerambycids reported from Prince Edward Island (McNamara 1991). The range map in Linsley \& Chemsak (1995) shows records from New Brunswick and Prince Edward Island. Downie \& Arnett (1996) report it from Labrador in Atlantic Canada and from two states in northern New England. The larvae feed on willow and poplar (Linsley \& Chemsak 1995, 1997).

\section{Saperda populnea moesta LeConte}

Cape Breton, Sydney Tar Ponds, 13 June 1996, Hudson, LA, UCCB

Cape Breton, Sydney Tar Ponds, 28 June 1996, Hudson, LA, UCCB

Victoria, Dingwall, 15 June 1983, Bousquet, Y, CNCI

This is a widespread species known in Canada from theYukon to Quebec (McNamara 1991). This species is not recorded from Atlantic Canada or northern New England in Downie \& Arnett (1996). The larvae feed on twigs of willow and poplar (Linsley \& Chemsak 1995, 1997).

\section{Saperda tridentata Olivier}

Eleven records, 17 specimens, Colchester (1), Cumberland (1), Halifax (1), Inverness (4), Kings (1), Pictou (1) and Victoria (2) Counties

This species is known from Saskatchewan to Quebec in Canada (McNamara 1991). Although they do not record it from Atlantic Canada, it is reported from two states in northern New England in Downie \& Arnett (1996). The larvae feed on elm (Linsley \& Chemsak 1995, 1997).

\section{Oberea deficiens Casey}

Kings, Lake Gg (George), 8 July 1948, Archibald, KD, NSMNH

This species is recorded from Ontario and Quebec in Canada (McNamara 1991). Yanega (1996) documented some of the problems associated with identification of Oberea spp. and distinguished between this taxon and the similar O. praelonga and O. ulmicola. This species is not included in either Downie \& Arnett (1996) or Linsley \& Chemsak (1995). This species appears to feed exclusively on viburnums (Yanega 1996).

Oberea pallida Casey

Halifax, Dartmouth, Cole Harbour, 28 July 1977, Hicks, SD, CNCI

Richmond, Grand River, 16 August 1931, Smith, CC, CFSF 
This species is known from Manitoba, Ontario and Quebec in Canada (McNamara 1991). Yanega (1996) clarified how to identify this species and showed that identifications reported in Linsley \& Chemsak (1995) are not reliable. The Cole Harbour specimen was caught on alder, the host according to Yanega (1996).

Oberea affinis Leng and Hamilton

Colchester, Debert, 11 July 1991, Georgeson, E, NSDNR

Colchester, Debert, 18 July 1991, Smith, TD, NSDNR

This species is known from Manitoba, Ontario and Quebec in Canada (McNamara 1991 ) and is not recorded for Atlantic Canada or northern New England in Downie \& Arnett (1996). The larvae feed on Rubus spp. stems (Linsley \& Chemsak 1995, Yanega 1996).

\section{Reported in McNamara (1991) or Downie \& Arnett (1996), no specimens in collections}

Typocerus acuticauda Casey

This species has a wide range in eastern North America from lowa and Manitoba east to Nova Scotia and Georgia (Linsley \& Chemsak 1976, McNamara 1991). Linsley \& Chemsak (1976) explicitly state the range extends to Nova Scotia and this is presumably the source of the report in McNamara (1991). They also suggest that this is a relatively rare species throughout its range. The larval host is unknown (Linsley \& Chemsak 1976, 1997).

\section{Brachyleptura vagans (Olivier)}

This species has often been confused with B. champlaini (Linsley \& Chemsak 1976, Yanega 1996). I suspect the inclusion in Downie \& Arnett (1996) is because of this confusion. All specimens of Brachyleptura in eastern Canada that have been examined are either $B$. champlaini or B. rubrica. This is consistent with $B$. vagans not being included in McNamara (1991) anywhere in eastern Canada.

Semanotus ligneus ligneus (Fabricius)

McNamara (1991) reports the cedar borer from Manitoba, Ontario, Quebec and Nova Scotia in Canada. Presumably the Nova Scotia record is included on the strength of a dot on the distribution map in Linsley (1964). This record appears to be in southern Annapolis County. White Cedar, Thuja occidentalis, is a very rare plant in Nova Scotia, but southern Annapolis County is one of the few places where it does occur (Pronych \& Wilson 1993, Roland 1998). Besides cedar, the larvae of S. ligneus feed in junipers and possibly other conifers (Baker 1972).

\section{Xylotrechus quadrimaculatus (Haldeman)}

This species is generally distributed in eastern deciduous forests from Manitoba east to New Brunswick and south into the south-central United States (Linsley 1964 Baker 1972, McNamara 1991, Yanega 1996). Larvae feed on twigs of birches, beech, and alder, all species that are common and widespread in Nova Scotia (Hosie 1990, Roland 1998). 


\section{Discussion}

Many species of cerambycids from Nova Scotia were not included in the two recent compilations examined by us (McNamara 1991, Downie \& Arnett 1996). The two compilations reported a total of 56 species, while 87 species were in the collections examined. It is sobering to think that we increased the number of species known in the province by about $64 \%$. It is also sobering to think that this is for a well-known group of beetles that are frequently collected by the generalist. The situation is undoubtedly worse for groups, such as the Phalacridae, Latridiidae, Elateridae and Staphylinidae for which basic taxonomy is still being worked out.

Despite the fact that they missed many species for Nova Scotia, the two recent compilations are effective in many ways. Bousquet's (1991) 'Checklist of Beetles of Canada and Alaska' is an invaluable tool. It has compiled much distributional information. Its weakness was the incompleteness of the information available. Apparently, the list of Cerambycidae (McNamara 1991) was compiled from Linsley and Chemsak's publications (see Linsley \& Chemsak 1997) and the $\mathrm{CNCl}$, but without reference to the collection of the Nova Scotia Museum or any other regional collection in Nova Scotia. The number of additions we compiled demonstrates the importance of these regional collections. It is also a signal that entomologists working with these regional collections need to publish distributional studies so that the information is available for broad compilations. Useful and comprehensive distributional works depend on the cooperation and exchange of information between regional and national natural history collections.

Downie \& Arnett's (1996) 'Beetles of Northeastern North America' is a noble attempt to compile identification keys for all beetles in the area. At this it is reasonably successful. Accurate distributional information would have been a useful addition to the keys. However, for Nova Scotia the distributional information is woefully inadequate, fewer than a third of the species of Cerambycidae are included.

Recognition of the Brown Spruce Long-horn Beetle created a tremendous controversy in Nova Scotia (e.g. Freedman 2001, Robertson 2001, Ricciardi 2001). An eradication program designed for spot infestations was put into place (Forestry Canada 2000), in this case a minimum of ten years after the introduction. Why did it take so long to recognize the problem? The short answer is that we did not have an accurate, basic inventory of Cerambycidae in Nova Scotia or the expertise to prepare such an inventory. Understanding wood boring beetles has not been a priority for the public, for government agencies or research institutions. With such a low priority the expertise has not been available. This lack of interest is not limited to the Cerambycidae as shown by this quote from a recent book on forest insect pests in Canada: "There is no current research being conducted in Forestry Canada on any of the wood-boring insects described in this chapter." (Safranyik \& Moeck 1995). Without the expertise or the inventory it is extremely difficult to recognize and identify a new arrival and as a result the specimens of Brown Spruce Long-horned Beetles sat misidentified, as a very similar native species, in a collection for almost 10 years.

The lack of expertise and lack of basic inventories has broader implications for conservation. Introduced species are recognized as the second most important risk factor for declines in species at risk, behind habitat loss. Through transport of novel pathogens, competition with similar native congeners, predation upon relatively poorly defended native species or alteration of natural community structure, introduced species may change the environment and contribute to population declines. Quick recognition of novel introduced species may mitigate the problems. However 
this is only possible if we know what the native species are, and this is only possible if knowing the native fauna is valued.

Recently introduced species may be the focus of eradication or control programs, such as that against Brown Spruce Longhorns. If we do not know what native species live in a broad area such as a whole province and fulfill similar ecological functions, how can we realistically determine whether attempts to eradicate a newly introduced species will be detrimental to native species - let alone uncommon or rare native species? For example the program to eradicate the Brown Spruce Longhorn from Point Pleasant Park in Halifax undoubtedly is killing numerous native cerambycids and other xylophagous beetles. Will populations of native species be exterminated? Are these species common or rare in the province? Point Pleasant Park is the only place in Nova Scotia where Tetropium schwarzianum is known. If this was a frog or salamander there would be no question that conservation of a rare native species would be granted some weight in the assessment of the eradication program. Our lack of knowledge and expertise in the distribution and abundance of cerambycid beetles compromises our ability to make wise decisions about both conservation and eradication efforts - which may not be uncoupled.

In summary, we have improved the inventory of cerambycid beetles and our understanding of the beetle fauna of Nova Scotia. Local and regional collections are a valuable resource that, combined with the major national collections, can provide a more complete inventory of beetles in Nova Scotia. Both regional and national collections need to be supported so that museum workers can make their findings known to ecologists and managers who in turn can effectively plan strategies for conservation, ecological monitoring and forest management in eastern Canada.

\section{Acknowledgments}

We thank the those responsible for the collections for access and assistance while working with their collections: Jeff Ogden and Eric Georgeson, NSDNR, Andrew Hebda, Calum Ewing, Alex Wilson and Barry Wright, NSMNH, Serge Laplante, Yves Bousquet, Jeff Cumming and Jeff Skevington CNCl, Randy Lauff, STFXU, Bob Anderson, Anne Howden and Henry Howden, CMN, Georgette Smith and Ken Harrison, CFSF, Chris Darling, Doug Currie and Brad Hubley, ROM. Serge Laplante graciously shared his expertise on the taxonomy, identification and biology of cerambycids with DBM. Chris Thomson and Steve Marshall helped in many different ways as this project progressed. Financial support was provided by NSERC operating grants to the authors and UCCB research grants to DBM.

\section{References}

Bousquet Y (1991) Checklist of beetles of Canada and Alaska. Research Branch, Department of Agriculture Publication 1861/E, Ottawa

Baker WL (1972) Eastern forest insects. USDA Misc Publ 1175, Washington, DC

Bily S, Mehl O (1989) Longhorn beetles (Coleoptera, Cerambycidae) of Fennoscandia and Denmark. Fauna Entomologica Scandinavica, Vol 22. E.J. Brill/Scandinavian Science Press, Leiden

Chemsak JA (1996) Illustrated revision of the Cerambycidae of North America, Vol I. Paradrinae, Spondylinae, Aseminae, Prioninae. Wolfsgarden Books, Burbank, CA 
Dearborn RG, Donahue CP (1993) The Forest Insect Survey of Maine, an annotated list of insects collected and recorded by the Maine Forest Service Order Coleoptera, Beetles. Maine Forest Service, Insect and Disease Division, Tech Rep 32

Downie NM, Arnett RH (1996) The beetles of northeastern North America. Sandhill Crane Press, Gainesville, FL

Forestry Canada (2000) Scientific background on Brown Spruce Longhorn Beetle (Tetropium fuscum) in Point Pleasant Park. http://www.fcmr.forestry.ca/fhn/ BSLBscience e.html

Freedman B (2001) Brown Spruce Longhorn Beetle, an invasive forest pathogen in the Halifax Regional Municipality. Biotype http://biotype.biology.dal.ca/biotype/2001/ feb01

Gosling DCL (1973) An annotated list of the Cerambycidae of Michigan (Coleoptera) Part I, introduction and the subfamilies Parandrinae, Prioninae, Spondylinae, Aseminae and Cerambycinae. Gt Lakes Entomol 6:65-84

Gosling DCL, Gosling NM (1977) An annotated list of the Cerambycidae of Michigan (Coleoptera) Part II, the subfamilies Lepturinae and Lamiinae. Gt Lakes Entomol 10:1-37

Hosie RC (1990) Native trees of Canada, $8^{\text {th }}$ edn. Fitzhenry \& Whiteside and Canadian Forestry Service, Toronto

Kehler D, Corkum C, Bondrup-Nielsen S (1996) Habitat associations and species diversity of forest beetle communities of Nova Scotia. Centre for Wildlife and Conservation Biology, Acadia University, Wolfville, NS

Laplante S, Bousquet Y, Belanger P, Chantal C (1991) Liste des especes de Coleopteres du Quebec. Fabreries, Supplement 6:1-136

Linsley EG (1961) The Cerambycidae of North America, Part I: Introduction. Univ Calif Publ Entomol 18:1-135

Linsley EG (1962a) The Cerambycidae of North America, Part II: Taxonomy and classification of the Parandrinae, Prioninae, Spondylinae and Aseminae. Univ Calif Publ Entomol 19:1-102

Linsley EG (1962b) The Cerambycidae of North America, Part III: Taxonomy and classification of the subfamily Cerambycinae, tribes Opsimini through Megaderini. Univ Calif Publ Entomol 20:1-188

Linsley EG (1963) The Cerambycidae of North America, Part IV: Taxonomy and classification of the subfamily Cerambycinae, tribes Elaphidionini through Rhinotragini. Univ Calif Publ Entomol 21:1-165

Linsley EG (1964) The Cerambycidae of North America, Part V: Taxonomy and classification of the subfamily Cerambycinae, tribes Callichromatini through Ancylocerini. Univ Calif Publ Entomol 22:1-197

Linsley EG, Chemsak JA (1972) The Cerambycidae of North America, Part VI: No 1 Taxonomy and classification of the subfamily Lepturinae. Univ Calif Publ Entomol 69:1-138

Linsley EG, Chemsak JA (1976) The Cerambycidae of North America, Part VI: No 2 Taxonomy and classification of the subfamily Lepturinae. Univ Calif Publ Entomol 80:1-186

Linsley EG, Chemsak JA (1984) The Cerambycidae of North America, Part VII: No 1 Taxonomy and classification of the subfamily Lamiinae, tribes Parmenini through Acanthderini. Univ Calif Publ Entomol 102:1-258

Linsley EG, Chemsak JA (1995) The Cerambycidae of North America, Part VII: No 2 Taxonomy and classification of the subfamily Lamiinae, tribes Acanthocinini through Hemilophini. Univ Calif Publ Entomol 114:1-292 
Linsley EG, Chemsak JA (1997) The Cerambycidae of North America, Part VIII: Bibliography, index and host plant index. Univ Calif Publ Entomol 117:1-534

McNamara JM (1991) Family Cerambycidae. In: Bousquet Y (ed) Checklist of beetles of Canada and Alaska. Research Branch, Department of Agriculture, Publication 1861/E, Ottawa, p 277-300

Pronych G, Wilson A (1993) Atlas of rare vascular plants in Nova Scotia, Vol 2. Nova Scotia Museum, Halifax

Ricciardi A (2001) Lessons from an ecological crisis: the Brown Spruce Longhorned Beetle. Biotype http://biotype.biology.dal.ca/biotype/2001/feb01

Robertson S (1990) Point Pleasant Park Halifax, Nova Scotia Bark Beetle Survey. Halifax Field Naturalists, Halifax

Robertson S (2001) History of Point Pleasant Park. Biotype http://biotype.biology.dal. ca/biotype/2001/feb01

Roland AE (1998) Roland's Flora of Nova Scotia, $3^{\text {rd }}$ edn. Nimbus Publishing and Nova Scotia Museum, Halifax

Safranyik L, Moeck HA (1995) Wood Borers. In: Armstrong JA, Ives WGH (eds) Forest insect pests in Canada. Canadian Forest Service, Ottawa, p 171-177

Smith G, Hurley JE (2000) First North American record of the Palearctic species Tetropium fuscum (Fabricius) (Coleoptera: Cerambycidae). Coleopt Bull 54:540

Yanega D (1996) Field guide to northeastern Longhorned Beetles (Coleoptera: Cerambycidae). Illinois Natural History Survey Manual 6, Champaign, IL 